\title{
OBITUARY
}

\section{DANIEL GEORGE EDWARD HALL}

D. G. E. Hall was born on 17 November 1891, the son of a Hertfordshire farmer, and received his early education at Hitchin Grammar School. In his late teens his love of music and fine bass voice inclined him towards a career as a professional singer, but the financial prospects were precarious and the opposition of family and friends strong. Instead he entered King's College in the University of London, where he graduated with first-class honours in modern history in 1916, winning the Gladstone Memorial Prize and an Inglis Studentship for postgraduate studies. For his M.A. thesis (the degree of Ph.D. not yet having been introduced into the University) he embarked upon a study of the mercantile aspects of English foreign policy during the reign of Charles II under the supervision of A. P. Newton, whose seminar on colonial history at this time also included Lilian Penson, later Professor of Modern History and Vice-Chancellor of the University. The thesis, which the modern reader will find chiefly notable for the vigour and clarity of its prose, is a well-balanced survey of the Restoration colonial system and the commercial rivalries of the European maritime powers, based on the then available printed sources.

By the time his thesis was successfully presented in June 1917, Hall had entered the Inns of Court Regiment, in which he served until the end of the First World War. After the war a number of different possibilities occupied his mind. Despite his earlier renunciation he had not altogether turned his back upon the world of music. Singing engagements had provided a helpful supplementary income during his time as a student, and during 1916 and 1917 he had, as opportunity offered, helped to entertain troops on the Western Front with the Lena Ashworth concert parties. As he mixed again with professional musicians he was clearly tempted to change his mind and to join their ranks. Another possibility was suggested to him during his time as a graduate student at King's College when, in addition to his research and a period as president of the Students' Union, he had also acted as an Assistant Lecturer, and the idea of university teaching as a way of life was an attractive one. For the moment, however, he found a post as senior history master at the Royal Grammar School, Worcester, moving during the summer of 1919 to a similar position at Bedales School in Hampshire. This gave him financial security, and enabled him to marry. The lady who now joined him at Bedales, as both his wife and a fellow teacher of history, had, as Helen Eugenie Banks, been two years junior to George Hall as an undergraduate at King's. Like him she had been awarded the Gladstone Memorial Prize, before beginning a career as a teacher.

Before they had completed two years at Bedales, Hall was offered and accepted the chair of history in the newly-founded University of Rangoon. The University of Rangoon came into existence in 1920 incorporating two constituent colleges, University College (formerly Rangoon College) and Judson College (formerly the American Baptist College), both of which had previously prepared students for the external degrees of Calcutta University. The new university started its career at a time of stress. Dyarchy, the first stage towards the achievement of the 'responsible' government promised to India in 1917 and embodied in the Government of India Act of 1919, was at first withheld from Burma. This evoked an outburst of Burmese national sentiment, and the quarrel between the Burmese nationalist leaders and the 
British Government was in full swing at the time of the foundation of the university. It was complicated by a dispute over the university itself. The government had rejected Burmese proposals for a system of external degrees to be taken by students in affiliated colleges at various places, including Mandalay, the centre of traditional Burmese culture. Instead, they opted for a centralized residential university in Rangoon, a cosmopolitan commercial and administrative city, where Burmans were in a minority. For many students the journey to Rangoon was a long and expensive one, and once there, they were exposed to an unfamiliar environment and a highly charged political atmosphere. The upshot was a widely observed boycott of government-sponsored colleges and schools and an attempt under nationalist auspices to organize an independent education system, free of government or missionary control. This state of affairs did not last long, and when the university re-opened in June 1921 after the long vacation, most of the students had returned. But the link between the university and politics, and the tradition of political activism among the student body, were to continue.

George Hall himself arrived in Rangoon in the middle of May 1921. Before leaving England he had spent a term studying Burmese at the School of Oriental Studies, then in Finsbury Circus. He had also looked at what little was then available in English on Burma's history, principally Phayre's History of Burma, published in 1883 and long out of print. But he was otherwise unbriefed and unprepared for the task ahead of him. Inevitably, therefore, some unpleasant surprises awaited him. The first was that no one in Rangoon knew anything about his appointment; the second, less easily remedied, that the new university's history syllabus had already been laid down by a committee headed by a historian especially imported from an Indian university for the purpose. This involved a heavy concentration on classical Greece and Rome, and on British and European history; such Asian history as was provided for was almost exclusively Indian. The syllabus committee had drawn up long lists of recommended reading, but no orders had actually been placed with any booksellers. Nor had the new professor, as yet, any colleagues to assist him in teaching, and students were already registering for the coming session, which was to begin in less than a month.

Inevitably, therefore, Hall's energies were at first absorbed in coping, almost on a day-to-day basis, with the teaching of the courses in Western history to which his department was already committed, and with the administrative burdens associated with his post. This involved not only the teaching itself, but in some cases the writing of textbooks appropriate to the needs of his students. Before he had been in Rangoon five years Hall had produced three such works: Imperialism in modern history (1923), A brief survey of English constitutional history (1925), and (as co-author) The League of Nations: a manual for university students ... in India, Burma and Ceylon (1926). At the same time, he was instrumental in bringing together the teachers of history in schools for discussion groups within the University, and in forming them into a branch of the Historical Association.

The other main focus of his attention during these early years was the struggle, against much prejudice and opposition, to secure the acceptance of new courses more relevant to the needs and background of the Burmese students of the time, and to assemble a group of colleagues who could teach these courses. The revised syllabus for which he eventually secured acceptance comprised world history, including an outline of the civilizations of the ancient Near and Middle East, India, and China, modern Western history, Indian 
history, and the history of East Asia, including a special study of Burma. As colleagues he found W. S. Desai to teach Indian history and G. H. Luce to teach Burmese and East Asian history; and, in the time left from fulfilling his other duties, he embarked on research which would serve to build up the Burmese content of the history syllabus.

Hall concentrated at first upon the problems of Anglo-Burmese relations. In 1928, he published Early English intercourse with Burma ${ }^{1}$ an exhaustive account of the subject from the reign of Elizabeth $I$ to the eighteenth century, which was followed in 1931 by 'The tragedy of Negrais'.$^{2}$ In 1932, there appeared The Dalhousie-Phayre correspondence, ${ }^{3}$ which continued the same theme into the nineteenth century, and gained for him the degree of Doctor of Literature from the University of London.

Developments at the University of Rangoon, too, gave cause for satisfaction. The institution was now housed on its own campus with halls of residence and a students' union building. Hall served in 1923 and 1924 as a temporary member of the Legislative Council of Burma during the amendment of the University Act which allowed the development of affiliated colleges elsewhere in Burma. He also acted as warden of one of the halls, and formed lasting relationships with many students.

But unhappy chance interrupted this optimistic progress. In $1931 \mathrm{Mrs}$. Hall and all five children developed trachoma and had to be sent back permanently to England. With the disadvantage of his rather specialized background, Hall faced the difficulty of finding the sort of post he needed at a time of severe retrenchment in the United Kingdom. He was forced to remain alone in Rangoon, returning on leave each year to see the family, until 1934, when he was offered the headship of Caterham School in Surrey which carried with it a house and free education for his three sons. There was nothing for it but to resign his post in Rangoon and return to schoolmastering.

Dr. Hall, as he was now known, retained the headship of Caterham from 1934 to 1949 , steering it through the difficulties of the Second World War, and building it up from a small and somewhat struggling institution to a thriving public school with its own preparatory school attached. In their way these achievements were as outstanding and as valuable as those of his years in Rangoon.

They were the more noteworthy in that they were accomplished without the relinquishment of the plan of scholarly activity he had conceived before he had to leave Rangoon. This plan was to expand his work on Burma into a wider history of European relations with South-East Asia as a whole, beginning with the arrival of the Portuguese early in the sixteenth century. In 1936 and 1939 he published two papers on Dutch trade in Burma and Arakan during the seventeenth century ; ${ }^{4}$ in 1945 came a major work, Europe and Burma, which surveyed the course of European relations with Burma from the sixteenth to the nineteenth centuries; ${ }^{5}$ and in 1950 Burma, a small volume in the Hutchinson's University Library series which, covering the entire history of

\footnotetext{
2 'The tragedy of Negrais', Journal of the Burma Research Society, 21, 1931, reprinted with Early English intercourse, London, 1968.

3 The Dalhousie.Phayre correspondence, 1852-1856, London, 1932.

4 'Studies in Dutch relations with Arakan', $J B R S, 26,1936$; ' The Daghregister of Batavia and Dutch trade with Burma in the seventeenth century', J $J R S, 29,1939$.

- Europe and Burma: a study of European relations with Burma to the annexation of Thibaw's kingdom, 1886, London, 1945.
}

1 Early English intercourse with Burma, 1587-1743 (London, 1928; reprinted London, 1968). 
the country in its highly compressed but very readable pages, is a small masterpiece. ${ }^{6}$ In addition, while at Caterham he produced two school textbooks on British history.

The Caterham period came to an end in 1949 when the University of London appointed Dr. Hall to the newly established chair of the History of South-East Asia at the School of Oriental and African Studies. His first acquaintance with this institution had been as a visiting student of Burmese before he first went to Rangoon. In the interval the School had moved to new premises on the central university precinct in Bloomsbury, and had extended its interests to Africa. It was now on the eve of a major expansion of its activities along the lines outlined in the report of the Scarbrough Committee, which had recommended the wider development of Oriental, African, and Slavonic Studies in Britain.

As one of the very few established British scholars of South-East Asia, Hall was expected not only to build up work in historical studies, but also to preside over the development of a department devoted to the languages and cultures of that area. Once again, as in the early years in Rangoon, the wider responsibilities of his post would have to take precedence over his own studies. During term-time for the next few years his working day was devoted once again to guiding the work of younger scholars, to the humdrum work of curriculum development, and to departmental administration. The result was the foundation of a school of South-East Asian history, staffed by himself and three colleagues, and the introduction, for the first time in any university of a full degree course in the subject. At the same time, he was responsible for appointments in Thai, Mon, Cambodian, Vietnamese and Pacific linguistic and literary studies, for a strengthening of the existing work in Burmese, Indonesian, and Malay, and for the creation of a post in South-East Asian art and archaeology. He was able also to bring into play once more his association with Gordon Luce, who at his invitation spent three years at the School as a visiting professor, conducting seminars and directing research.

Against the background of this investment of his time in building a framework for the future development of South-East Asian studies in London, his mind was already at work on an ambitious project of his own, a general history of South-East Asia. Earlier he had thought in terms of a history of European relations with the area. To attempt a history of South-East Asia itself had seemed beyond his powers, the many language skills required to deal with masses of unworked materials beyond the compass of a single scholar. Now, although there were still many parts of the subject on which little or nothing had been done, the amount of secondary material available from the work of other scholars was beginning to accumulate, and for an English scholar with a reading knowledge of Dutch and French the task began to seem within the bounds of possibility. From 1950 onwards he set himself to collect material bit by bit, during the intervals of his working day, and to tussle with the intractable problems of the organization of the work as the earlier draft chapters began to take shape. He and Mrs. Hall had now settled into a new home in Hitchin, in the area in which his youth had been spent and where several of his family still lived. The pattern of his student days, when he had travelled up to King's College daily by train from Hitchin, was now re-established, though, as he remarked somewhat wryly to colleagues, the fact that the trains now took longer and were less often on time enabled him to do more reading.

${ }^{6}$ Burma, London, 1950. (Revised ed., 1956.) 
In 1952 and 1953 a period of study leave enabled him to make lengthy visits to Indonesia, Thailand, Malaya, and Burma. He lectured, talked with scholars, politicians, and former students, and visited important historical and archaeological sites.

The great History of South-East Asia which was completed and published in 1955, was a formidable achievement. ${ }^{7}$ It was the first full-scale history of the area in any language. Modestly described by its author in his preface as ' a bare outline, perilously compressed and oversimplified in many parts', it embraced within its forty-five chapters and extensive bibliography the results of virtually all the then existing secondary literature on the subject, and paid generous tribute to the authors on whose work it drew. Together with the many translations which were to appear during the next fifteen years it signalled to the scholarly world the emergence of a new and distinct field of study.

The History of South-East Asia was the centrepiece of the published work which appeared over Hall's name during his tenure of his chair in London, but there was much else besides. In addition to producing numerous articles he also collected and edited for the press Michael Symes's journal and other documents connected with the latter's second embassy to the court of Ava in $1802 .^{8}$ Professor Hall had played the principal part in organizing the SouthEast Asian section of a conference on historical writing on the peoples of Asia held in London in 1956. The resulting volume of papers on South-East Asian historiography which was published under his editorship in $1961{ }^{9}$ demonstrated in a remarkable fashion the great strides which had been made in the development of this field since the end of the Second World War.

For this indefatigable scholar it was very much in character that his attainment of the University of London's mandatory retirement age in September 1959 merely provided him with an opportunity to embark on yet another phase of his career. This was made possible by his association with Cornell University, already the best-known centre of South-East Asian studies in the United States. Hall's connexions with it had been developing since 1952, and he was now free to take up a long-standing invitation to a visiting professorship there. The arrangement proved a happy one. Cornell's beautiful campus at Ithaca, in the 'finger lakes' region of upstate New York, became for him a second home and for the next fourteen years his time was divided between it and Hitchin, with occasional teaching assignments to other universities in North America and Australia. It was a period clouded only by the fact that Mrs. Hall was not to share it with him. She became ill soon after their arrival in Cornell, and died in Hitchin after a long illness in 1962.

Despite this personal tragedy, however, Hall's infectious enthusiasm for his subject and his zest for teaching remained undiminished. He delighted in the day-to-day contact with younger scholars, and the opportunity it gave him to keep in touch with fresh minds and with the increasing spate of new contributions to South-East Asian studies. He also played an active part in the conferences of the Association of Asian Studies and the American Historical Association, presenting and publishing many papers of importance for the development of South-East Asian historiography. New and substantially enlarged editions of $A$ history of South-East Asia appeared in 1964 and 1968, 1968.)

${ }^{7}$ A history of South-East Asia, London and New York, 1955. (Second ed., 1964 ; third ed.,

Michael Symes, journal of his second embassy to the Court of Ava in 1802, ed. D. G. E. Hall, London, 1955.

D. G. E. Hall (ed.), Historians of South-East Asia, London, 1961. 
and when he returned to England from Cornell for the last time in 1973 he brought with him the completed text of a study of Henry Burney, British envoy to Thailand and the first Resident at the Court of Ava. ${ }^{10}$

In his last years things were made more difficult for him by failing eyesight. George Hall had lost his left eye as the result of an infection which developed behind it during a severe attack of influenza in 1941. For thirty years, while maintaining a strenuous regimen of daily work, he had made one eye do the work of two. Now he began to suffer from recurring haemorrhages from the blood-vessels behind the right eye, which deprived him of sight for weeks at a time. In 1976, when a group of his friends, colleagues and former students published a volume of essays in his honour, ${ }^{11}$ he was just able by great efforts to read them all and write a few words of appreciation to each contributor. Soon afterwards he became quite blind. But he remained physically robust, and with the help of a devoted secretary continued to write and to deal with a large correspondence with a legion of friends and scholars seeking advice from all over the world. Throughout a long life no one ever approached him for help or advice in vain.

Two days before suffering the stroke from which he died on 12 October 1979 , he dictated the last paragraph of an appreciation of the life and work of his friend, Gordon Luce, for BSOAS (xuIII, 3, 1980). Hall himself referred to this in memoriam piece as ' a labour of love'. That phrase most aptly describes the life's work of D. G. E. Hall.

C. D. COWAN

${ }_{10}$ Published as Henry Burney: a political biography, London, 1974.

11 C. D. Cowan and O. W. Wolters (ed.), South-East Asian history and historiography: essays presented to D. G. E. Hall, Ithaca and London, 1976. 